\title{
Response of Caenorhabditis elegans during Klebsiella pneumoniae pathogenesis
}

\author{
Arumugam Kamaladevi, Krishnaswamy Balamurugan ${ }^{*}$ \\ From 2nd International Science Symposium on HIV and Infectious Diseases (HIV SCIENCE 2014) \\ Chennai, India. 30 January - 1 February 2014
}

\section{Background}

Caenorhabditis elegans, owing to its amenability and conserved innate immune system was recognized as an emerging model to dissect the molecular basis of many mammalian infections. Klebsiella pneumoniae causes severe infections in immunocompromised patients. Hence, the host response was studied using C. elegans during $K$. pneumoniae infection.

\section{Methods}

Pathogenicity of $K$. pneumoniae and its LPS were assessed by variety of physiological and biochemical assays. The qPCR was used to analyze the regulation of innate immune genes.

\section{Results}

K. pneumoniae and its LPS were lethal to C. elegans and required $48 \pm 5$ hours and $24 \pm 3$ hours for complete killing, respectively, with cessation of pharyngeal pumping and egg laying. Infection with $K$. pneumoniae increased the bacterial load in the intestine of host upon course of infection, which was measured as $1.5 \times 10^{3}, 2.2 \times 10^{3}$, $3.6 \times 10^{4}$ and $3.7 \times 10^{5}$ in $4,6,12$ and 24 hours, respectively. This increased bacterial load subsequently disseminates oxidative stress markers in host. The level of ROS was measured to increase by $24.36597 \mathrm{nM}, 35.60517 \mathrm{nM}$, $39.34052 \mathrm{nM}$, and $28.24774 \mathrm{nM} / \mathrm{mg}$ of protein in $6,12,24$, and 36 hours, respectively. Infection by K. pneumoniae also increased the protein carbonyls to $25.57 \mathrm{nM}, 36.14 \mathrm{nM}$, $35.26 \mathrm{nM}$ and $38.84 \mathrm{nM} / \mathrm{mg}$ of protein in $6,12,24$, and 36 hours, respectively. K. pneumoniae and its LPS suppressed the expression of $p m k-1$, to $1-1$ and antimicrobial peptides (clec-60, clec-85, clec-87, lys-1, and lys-7) and thus

\footnotetext{
* Correspondence: bsuryar@yahoo.com

Department of Biotechnology, Alagappa University, Science Campus, Karaikudi, India
}

\section{and take full advantage of:}

- Convenient online submission

- Thorough peer review

- No space constraints or color figure charges

- Immediate publication on acceptance

- Inclusion in PubMed, CAS, Scopus and Google Scholar

- Research which is freely available for redistribution

Submit your manuscript at 